\title{
Becoming National? G. M. Trevelyan: The dilemmas of a liberal (inter)nationalist, 1900-1945
}

\author{
Alastair MacLachlan
}

On the face of it, biography, with its focus on intimate, personal identity, seems an unpromising genre for addressing the public, collective idioms of nationalism. But arguably the national is but 'one dimension in which a general theory of identity...can be investigated'. ${ }^{1}$ And the biographical mode may offer insights into specificities, complexities and antinomies occluded in broader, impersonal studies of national identity.

George Macaulay Trevelyan was not a profound thinker about nationalism. He was primarily a narrative historian, a celebrant not an analyst of nationalist movements, but his career, nevertheless, illustrates some of the dilemmas of a liberal (inter)nationalist in the period 1900-45. Son of George Otto Trevelyan, a leading liberal of the Victorian era, great nephew of Lord Macaulay, he had an identity firmly rooted in the interlocking family networks of England's political and intellectual aristocracy. He grew up primarily at Wallington, the ancestral home on the edge of the Northumbrian moors. In the writing room stood the desk where Macaulay wrote his History of England; in the study, the table where his father completed his Life and Letters of Lord Macaulay weeks before Trevelyan's birth. Its vast central hall was decorated with scenes of local history from Roman times to the 1860s, 'interspersed with portrait medallions of famous Northumbrians, starting with the Emperor Hadrian and culminating with midnineteenth century Trevelyans' ${ }^{2}$

Houses like Wallington provided tangible moorings for elite Victorian families like the Trevelyans, enshrining family archives, memories and emotions, linking its inhabitants to the neighbourhood and to similar families throughout the country; they were palimpsests of local and national history. ${ }^{3}$ The same was true of the grounds and surrounding countryside, whose history Trevelyan evoked in some of his early essays. For, like many such families, the Trevelyans cared as much for the rural setting as for the house itself. 'Trevy' was himself one of those late-Victorian 'pilgrims of scenery', for whom 'landscape theology' served as a substitute for religion. So, when he thought of Wallington, he thought

\footnotetext{
Jonathon Hearn's essay in this volume.

Collini, S. 1999, English Pasts, Essays in History and Culture, Oxford University Press, Oxford, pp. 20-1.

Tolley, C. 1997, Domestic Biography, Oxford University Press, Oxford, especially Ch. 1.
} 
immediately of the Northumbrian moors and 'the sheep runs that sweep up to the Scottish border', which he walked obsessively. For him, walking, especially hill and mountain walking, was both a daily tonic and a spiritual experience: 'the best means whereby a man might regain possession of his own soul, by rejoining him in sacred union with nature.' ${ }^{4}$ And the appeal was not just to the 'solitude [and] silence of primeval nature', but to its literary, historical associations. Thus, Wallington for him also connoted Hadrian's Wall, the Middle Marches, the Border ballads and a heroic Anglo-Scottish warrior past. His devotion to English literature - apparent in everything he wrote - was an essential part of his sense of place and his feeling for nature, history, and local and national identity. Richly chronicled in prose and verse, the English countryside for him was a 'storied landscape', filled with associations and attachments. ${ }^{5}$

But the very naturalness of his privileged national belonging prevented him from asking searching questions. Englishness, like history and liberal politics, was an almost invisible environment of which he was barely aware. It was only in later life, when the social fabric, the environment and England itself were under threat, that he became a self-conscious celebrant of his own national identity - notably in his English Social History, a work explicitly 'confined to the social history of England', written between 1940 and 1941, though only published in $1944 .^{6}$

Before 1914, his Englishness was underscored and a broader British patriotism repressed by political radicalism and dislike of empire. Though not unusual, this was family tradition, too: his father was a fierce critic of the post-Mutiny Raj and, unusually, a supporter of Scottish home rule. Trevelyan himself was in the habit of signing his youthful letters 'God Save Ireland' or 'God Save the People' (GSI or GSP for short). As a student, he had quarrelled with the Regius Professor J. R. Seeley over what he saw as the latter's illiberal, expansionist reading of English/British history. ${ }^{7}$ He cut his political teeth during the Boer War; and, as the British authorities locked up settler families in concentration

4 Cannadine, D. 1992, G. M. Trevelyan: A life in history, Harper Collins, London, pp. 144, 146 ff; Trevelyan, G. M. 1913, 'Walking', Clio, A Muse and other Essays, Longmans, Green \& Co., London, pp. 1-19, especially pp. 3-4.

5 Lowenthal, D. 1985, The Past is a Foreign Country, Cambridge University Press, Cambridge, pp. 8, 248-9; Trevelyan, G. M. 1949, The Autobiography of an Historian, Longmans, Green \& Co., London, pp. 11, 24-6; Trevelyan, G. M. 1913, 'The middle marches', in Clio, pp. 19-41.

6 Trevelyan, G. M. 1944, English Social History, Longmans, Green \& Co., London, pp. vii, 416.

7 Wormell, D. 1980, Sir John Seeley and the Uses of History, Cambridge University Press, Cambridge, pp. 128, 130-3; Seeley, J. R. 1883, The Expansion of England, Cambridge University Press, Cambridge; Seeley, J. R. 1895, The Growth of British Policy, Cambridge University Press, Cambridge. The particular object of Trevelyan's ire was Seeley's attack on Whig history in 'History and politics' (Macmillan's Magazine, 1879, p. 40). 
camps and painted Africa red from Cape Town to Cairo, he deplored the jingoistic imperialism of the age: 'the mother of freedom', he lamented, 'has become the Austria of the twentieth century' ${ }^{8}$

His 'Little Englandism' was complemented by firm belief in self-determination. Before 1914, his feelings about nationality focused on other peoples' struggles for nationhood - stories more recent, contingent and heroic than England's. He was a prominent liberal internationalist of the pre-1914 era, and a member of various committees formed in support of national independence movements in Eastern and south-eastern Europe and the Middle East, including the Finnish, Macedonian, Persian and Balkan Committees. Like his friend Robert SetonWatson, as a well-heeled patrician, he travelled extensively: Italy every year, but also Hungary, Romania, Serbia and the Balkans. And his travels, like his histories, were a continuation of politics by other means.

A historian by choice, he regarded his histories not as academic exercises but as 'Liberal Tracts for the Times'; in 1903, he abandoned what he considered a sterile university career for a 'more useful life', writing books that would 'make a permanent difference'. For the essence of Victorian liberalism was not a fixed ideology but an implicit language about the past and how the present had grown out of it. ${ }^{9}$ His histories of nationhood imagined, anticipated, fought for, achieved and grew naturally out of the time-honoured story of English religious, political and economic freedoms. As a pupil of Acton and a New Liberal, he viewed nationalism as 'a modern idea, which could exercise its full force only in a society, where freedom was recognised as one of the most precious human possessions'. For national self-determination involved not just liberation from foreign rule and autocracy, but also the reawakening of national culture and creation of a truly democratic ethos. It embodied J. S. Mill's teaching on liberty, happiness and secular toleration and T. H. Green's on moral development and full citizenship in the 'ethically enabling state'. This, he believed, had been achieved in America and France during the late eighteenth century, and in Greece and Italy during the nineteenth. And he hoped it could now be fulfilled in Eastern and south-eastern Europe and the Near East. ${ }^{10}$

\footnotetext{
8 Trevelyan, G. M. 1901, Letters to The Times, 23 and 31 October; Trevelyan, G. M. to Charles P. Trevelyan, 20 October 1901, Trevelyan Papers, Robinson Library, University of Newcastle, Newcastle, UK CPT 237 (2). 9 Trevelyan, G. M. to Charles P. Trevelyan, 1 March 1903 and 1 and 18 December 1905, Trevelyan Papers, Robinson Library, CPT Ex 201, 202; Cannadine, G. M. Trevelyan, p. 71; Moorman, M. 1980, George Macaulay Trevelyan, A Memoir, Longmans, Green \& Co., London, pp. 46, 51; Feske, V. 1996, From Belloc to Churchill: Private scholars, public culture and the crisis of British liberalism 1900-1939, University of North Carolina, Chapel Hill, pp. 4-5, 141-2, 150.

10 Acton, J. E. 1907, 'Nationality', in J. N. Figgis (ed.), A History of Freedom and Other Essays, Cambridge University Press, Cambridge; Simonhy, A. and Weinstein, D. 2001, The New Liberalism: Reconciling liberty and community, Cambridge University Press, Cambridge, pp. 17-18, 209 ff; Vincent, A. 1986, The Philosophy of T. H. Green, Macmillan, Aldershot, UK; Trevelyan, G. M. 1903, 'A plea for a new programme', The Independent Review, pp. 1-17.
} 
From the defeat of Napoleon until 1914, the connection between liberalism and nationalism to him seemed obvious: a result of the consolidation in 1815 across Central and Eastern Europe of deeply conservative, multinational, military empires and the analogous convergence of reformist political agendas and movements for national unity and liberation within and across frontiers. As he explained in a series of essays written during World War I combining meta-history and propaganda, ever since Waterloo, continental Europe had been subject to 'the iron law' of Prussian, Austrian and Russian imperial power. Initially, it had 'triumphed in the spirit of mere negation: the Dead Hand which Metternich transmitted from the Chancelleries of the ançien regime' ${ }^{11}$ So it was that 1830 and 1848, the years of revolution against the 'Old Corruption', were also 'Spring-time' years 'of nations'. Nowhere was this clearer than in Italy-and specifically Rome - where in 1848-49, Mazzini and Garibaldi established their short-lived republic. It was a remarkable experiment in democratic government: open, tolerant, secular, based on universal suffrage and on Mazzini's principles of interlocking political rights and social duties - quite different from the Papal regime it displaced, hyperbolically described by Trevelyan as 'the most ancient and terrible theocracy in the Western world' ${ }^{12}$

Trevelyan's most famous work before 1914 was the Garibaldi Trilogy, his celebration of Italian nation-making from 1848 to 1861, the first volume timed to coincide with the centenary of Garibaldi's birth, the last with the fiftieth anniversary of the modern Italian state. It was the perfect national liberation story. Unlike the chequered narrative of English freedom, Italian 'liberation' was concentrated on 'the Risorgimento', the 'one all embracing movement: a time when a whole people acquired a Faith and its history became spirit-serving and notable'. Unlike England, the Italian state did not evolve over centuries; it was made and made quickly. And its makers, in Trevelyan's eyes, were men of incomparable nobility: Mazzini, the prophet, Cavour, the statesman, above all, the poet-warrior, Garibaldi, 'the incarnate symbol of two passions not likely soon to die out of the world, the love of country and the love of freedom' ${ }^{13}$

11 Trevelyan, G. M. 1919, The War and the European Revolution in Relation to History, Creighton Lecture London University, Athlone Press, London, pp. 29, 35; Trevelyan, G. M. 1918, 'From Waterloo to Marne', Quarterly Review, vol. 229 (June), p. 77 ff; Trevelyan, G. M. 1918, 'The four great wars', Edinburgh Review, October, pp. 216, 265-75.

12 Trevelyan, G. M. 1907, Garibaldi's Defence of the Roman Republic, Longmans, Green \& Co., London, p. 70; Trevelyan, G. M. 1909, Garibaldi and the Thousand, Longmans, Green \& Co., London, p. 3; Cannadine, G. M. Trevelyan, pp. 67-8.

13 Trevelyan, Garibaldi's Defence of the Roman Republic, pp. 23-4; Trevelyan, Garibaldi and the Thousand, pp. 7-8. It may be claimed that all nations, England included, are 'made', if by 'made', one means 'imagined'. But Italy's construction as a unitary state in the period 1859-70 is clearly of a different order from the long process of state formation in England - and in Britain also. For a 'short view' of a late-nineteenth-century construction of a specifically English nationalism, see Kumar, K. 2003, The Making of English National Identity, Cambridge University Press, Cambridge. For a longer historical perspective on England, see MacLachlan, A. D. 1997, 'Patriotic scripture: the making and unmaking of English national identity 1500-1800', in S. Jack (ed.), Festschrift for Patrick Collinson, Parergon, Sydney, pp. 1-34; Hastings, A. 1997, The Construction of 
The Garibaldi story in his opinion was 'the most romantic...history records', and he told it with 'ardour and fury'. ${ }^{14}$ A disciple of Carlyle, he was a great hero worshipper, and his trilogy perfectly fused the hero's life with the liberal morality tale - the early training in freedom fighting, the forging of character through adversity in 1849, the victory against impossible odds in 1860, and then the consolidation, the quiet retirement - a transcendent romance of 'all the elements whereby history becomes inspiring, instructive and dramatic'. Garibaldi's greatness lay in his legend; and his was not conventional history, but a retelling of the legend-a legend 'which turns out on examination to be true'. ${ }^{15}$ In the 1850s and 1860s, Garibaldi had become a global cult figure-nowhere more than in England, which he visited in 1854, when he and Mazzini were welcomed as 'champions of...an enslaved country by the working men of Tyneside' on a visit partly financed by the Trevelyans; and, 11 years later, when the ovation given the 'redeemer of Italy' was 'universal and overwhelming'. ${ }^{16}$ Alongside Garibaldi, the other hero of Trevelyan's books was Italy. Italy, as A. N. Wilson observed, tapped all 'the sunniness and optimism' of the Victorian character. ${ }^{17}$ What Trevelyan described as her 'unrivalled appeal to the imagination' inspired English artists, poets and politicians throughout the nineteenth century. And nowhere were the connections stronger than at Wallington. George Otto had gone to Italy to fight for Garibaldi in 1867, an adventure he regarded 'as the greatest romance of [his] life'; and Garibaldi saluted the family every day from the last of the historical panels in Wallington's central hall. ${ }^{18}$

'That there should ever have been a time when Mazzini ruled Rome and Garibaldi defended her walls sounds like a poet's dream.' Trevelyan's avowed aim in Garibaldi's Defence of the Roman Republic was 'to give shape to that dream' by telling the story of Mazzini's doomed experiment, Garibaldi's heroic defence of the Republic and inevitable defeat, followed by his epic retreat across the Apennines, the death of his wife, Anita, in his arms and his own eventual escape into exile. Ostensibly, it was a human and political tragedy, but Trevelyan made

\footnotetext{
Nationhood: Ethnicity, religion and nationalism, Cambridge University Press, Cambridge, pp. 35-65; Murray, A. V. (ed.) 1995, Concepts of National Identity in the Middle Ages, Graduate Centre for Medieval Studies, University of Leeds; especially essays by A. D. Smith, J. Gillingham and L. Colley in Britons: Forging the nation, 1707-1837, 1992, Yale University Press, New Haven, Conn.; Davies, N. 1992, The Isles, A History, Macmillan, London.

14 Moorman, George Macaulay Trevelyan, p. 102.

15 Riall, L. 2007, Garibaldi, The Invention of a Hero, Yale University Press, New Haven, Conn., and London, pp. 13-14; Trevelyan, G. M. 1911, Garibaldi and the Making of Italy, Longmans Green \& Co., London, p. 296. 16 Trevelyan, Garibaldi's Defence of the Roman Republic, Preface, p. 2; Trevelyan, Garibaldi and the Making of Italy, pp. 289-91; Riall, Garibaldi, pp. 125, 330-44; Beales, D. 1991, 'Garibaldi in England: the politics of Italian enthusiasm', in J. A. Davis and P. Ginsborg (eds), Society and Politics in the Age of the Risorgimento, Cambridge University Press, Cambridge, pp. 184-216.

17 Wilson, A. N. 2003, The Victorians, W. W. Norton \& Company, New York, p. 84.

18 Cannadine, G. M. Trevelyan, p. 66; 'A memory of Garibaldi: Sir G Trevelyan's experience', The Times, 17 December 1925.
} 
it a triumph also, by prefiguring its resolution in national unification 11 years later, and by infusing it with the poetry he later anthologised in his English Songs of Italian Freedom. ${ }^{19}$

But it was the author's own experiences re-enacting the scenes of Garibaldi's resistance, following in Garibaldi's footsteps, re-treading 'the whole route traversed by [his] column from the gate of Rome to...the Adriatic', which, he said, 'taught me that Italy is not dead but risen, that she contains not only ruins but men, that she is not the home of ghosts but the land which the living share with their immortal ancestors'.$^{20}$ Part biography, part history, part travelogue, this was his most poetic text. His second and third volumesGaribaldi and the Thousand, telling the story of the famous Sicilian expedition, and Garibaldi and the Making of Italy, tracing the conquest of the Kingdom of Naples - were triumphalist. But here again, the storyline was enhanced by his intimate knowledge of the terrain, as he retraced his hero's marches across the most inaccessible parts of Sicily and southern Italy. By reliving and writing Garibaldi's story, Trevelyan, the frustrated political activist, acquired a second, adventitiously heroic identity, fusing his own persona with his protagonist and his protagonist's agency with a collective Italian agency: the personal and the national. ${ }^{21}$

Students of national identity commonly have distinguished 'liberal nationalism', based on citizenship and political rights, articulated in constitutions and representative institutions, from a 'romantic nationalism', based on blood, soil and belonging, expressed in language, poetry, folk music and landscape rather than in political arrangements. ${ }^{22}$ Trevelyan's perception of nation formation in Italy, which was both liberal and romantic, suggested it could be both. And because unification was the work of three very different men - the liberal constitutional monarchist Cavour and two distinctive romantic republicans, Mazzini and Garibaldi- - he was possibly right.

To work effectively as a popular ideology, writes John Breuilly, nationalism 'needs simplification, concreteness and repetition'; and Trevelyan's style of altruistic nationalism was all of these things. ${ }^{23}$ But because his attachment was so total, he never addressed the difficult issues of nation formation: the extent to which Italy was 'made' by others, was incompletely made and remained divided;

19 Trevelyan, Garibaldi's Defence of the Roman Republic, p. 4; Trevelyan, G. M. 1911, English Songs of Italian Freedom, Longmans, Green \& Co., London.

20 Trevelyan, Garibaldi's Defence of the Roman Republic, p. 7.

21 Hearn, this volume.

22 This distinction was the organising principle of the pioneer studies of nationalism by Hans Kohn and Carleton Hayes, and it can still be found explicitly in works such as Greenfeld, L. 1992, Nationalism: Five roads to modernity, Harvard University Press, Cambridge, Mass.; and Ignatieff, M. 1994, Blood and Belonging: Journeys into the new nationalism, Farrar, Strauss \& Giroux, New York.

23 Breuilly, J. 1993, Nationalism and the State, Manchester University Press, Manchester, pp. 62-4. 
or the degree to which his three 'miracle men' wanted quite different things: in Mazzini's case an integral democratic Republic, in Cavour's a territorially enlarged Piedmont, in Garibaldi's - for Garibaldi was a simplifier and an 'outsider' too $^{24}$ — an ill-defined, idealised Italia. By ending his narrative with Italy ostensibly 'made' in 1860, he also avoided the inglorious denouement: the protracted civil war in the south; Garibaldi's failed marches on Rome; Mazzini's death in bitter exile. More seriously, he never queried the existence of a common Italian identity - a national character, a clearly defined territory and a mission which, as Mazzini said, was 'God-given' — and never asked whether Romans or Neapolitans saw themselves as Italians and were better off in a unified Italy than under their ancient rulers. ${ }^{25}$

In many ways, Italy remained an unfinished, dissatisfied nation. Francesco Crispi, Garibaldi's lieutenant in Sicily, was not alone in calling for a 'purifying' war that would make Italians 'in a moral sense'. After 1860 Italy did not need to go to war, but on five occasions over the next 50 years she did: twice in Europe, three times in Africa. From the 1880s there was much agitation for colonial conquests; and Crispi, having failed to cajole Bismarck into a joint attack on France, sought in Africa the glory that eluded him in Europe. But the invasion of Ethiopia, proclaimed by Garibaldi's son, 'a renewal... of the splendour of Garibaldi's victories', led to the military disaster of Adowa in 1895, where Italy lost more men than in all her wars of independence. ${ }^{26}$ None of this registered in Trevelyan's account. 'Nothing', he concluded in 1911, 'is more remarkablethough to believers in nationality and ordered liberty nothing more naturalthan the unity and stability of the Italian Kingdom... The power [of] this great national movement has been directed only to the securing of Italian liberty, not to the oppression of others' ${ }^{27}$

This was never entirely true; but by the time his words were published, they spectacularly had fallen foul of the imperatives of Italian imperial expansion.

Unusually for Trevelyan, the book went to press later than intended-at the end of September 1911 - and he could not have chosen a worse moment. On 29 September Italy began her invasion of Libya. Trevelyan was appalled: the oppressed nation had become the imperial oppressor. But he could make little sense of it, save that the current crop of leaders had lost the idealism of the Risorgimento and that the materialists and militarists had taken over: 'the action

\footnotetext{
24 He was born in Savoyard Nice, which was given to France in 1859.

25 Duggan, C. 2008, The Force of Destiny: A history of Italy since 1796, Allen Lane, London, pp. 217-73; Gilmore, D. 2008, 'Garibaldi's gift', New York Review of Books, 26 June; Gilmore, D. 2011, The Pursuit of Italy, Penguin Books, London, pp. 238-63; 'The end of Italy', Foreign Policy, 15 November 2011.

26 Duggan, The Force of Destiny, pp. 345-8; Duggan, C. 2002, Francesco Crispi: From nation to nationalism, Oxford University Press, London, pp. 698-702.

27 Trevelyan, Garibaldi and the Making of Italy, pp. 294-5; Trevelyan, G. M. 1911, 'The festival of Italian unity', The Times, 27 March.
} 
of the degenerate Italians of today in going to conquer another race', he wrote, 'takes the heart out of me as far as my books are concerned'. ${ }^{28}$ For it must have been galling to read reviews of his work alongside news of Italian war crimes, even more to be taken to task by harsher reviewers 'on the evidence of recent events' for misrepresenting history and promoting 'Italian illusions' ${ }^{29}$

It may have been his Italian experience that explained the national liberation story he did not write. Early in 1912 he spoke at the Workingmen's College in London on 'race nationalism': 'Race Nationalism...the passion for your race as a political entity', as distinct from civic patriotism, a 'cultural, historical and traditional affair', was modern and biologically determined.

It is simply a fundamental passion which I might compare in all reverence with the great reproductive passion of sex - not a thing which is good or bad in itself - but a great forcing power responsible for so much of the poetry, idealism and purpose in the lives of men and productive of the highest forms of political and military nobility and self-sacrifice that adorn the history of all countries but also responsible for race rivalry and hatred which have led to great cruelties and horrors. ${ }^{30}$

A year later, he was invited by the Serbian military authorities to visit the battlefields of the recently victorious first Balkan War. Filled with heroic images of Garibaldi's campaigns, he responded warmly to the historical romanticism of his hosts and to the legends of Serbian history: evocations of the great medieval empire of Stefan Dusan 'five hundred years ago before the Turkish flood' and 'the thrill of contemporary battle amidst the untamed beauties of the Balkan landscape'. ${ }^{31}$ What he recorded on that '[h]oliday among the Servians' was a sanitised war of liberation with the rivalries, atrocities and 'ethnic cleansing' omitted, and the Serbs as bringers of freedom to Kosovo, Macedonia and Albania. But once bitten, twice shy, and he discreetly ducked requests for a history of the recently completed wars of independence after the manner of his Italian volumes - a refusal he attributed to his 'sense of the complexities of the Balkan problem....and the multitude of conflicting racial standpoints, each reasonable in itself were it not for all the others', but which may have stemmed from a reluctance to submit this Risorgimento to liberal examination. He was

28 Trevelyan, G. M. to Robert Trevelyan, 4 October and undated mid October 1911, in Raina, P. 2001, George Macaulay Trevelyan, A Portrait in Letters, Pentland Books, Durham and Edinburgh, pp. 74-5.

29 'Italian illusions', Saturday Review, 18 November 1911, p. 647; English Historical Review, vol. XXVII (January 1912), p. 174.

30 Trevelyan, G. M. 2012, 'Race nationalism', Workingmen's College Journal, (March), pp. 278-9.

31 Trevelyan, G. M. 1913, 'A holiday among the Servians', Contemporary Review, civ, pp. 153-63; 'The Servian armies and its Turkish victories', Nation, 19 July 1913; Moorman, George Macaulay Trevelyan, pp. $120-3$. 
also convinced that the Serbians, like the Russians, 'wouldn't produce a man as attractive as Garibaldi'. So there was no identification with a heroic protagonist, and hence no process of altruistic national encoding through narrative. ${ }^{32}$

A year later, as war on the Continent loomed, along with many radical intellectuals initially, he favoured British neutrality. Immersed in his biography of Lord Grey of the Reform Bill, he had just reached the year 1792, and the coming of what he called 'the unnecessary war' against revolutionary France: the war that had 'barbarised' Europe for 20 years, had set back national independence movements for a generation and, when it was over, had handed continental Europe back to Russian, Austrian and Prussian imperial power and the ancien régime. ${ }^{33}$ Tearing himself away from 'the colossal waste and wickedness' of that war, he rushed up to London at the end of July for what he called 'last hour neutrality work', speaking at the Trafalgar Square peace rally on 2 August and adding his name to statements denouncing the war as a threat to 'Western civilization' ${ }^{34}$

By mid August, however, the advance of the German military juggernaut across northern Europe had persuaded him that unless the Germans were beaten, 'civilization, as we know it, is done for'. ${ }^{35}$ By a characteristic quirk of the liberal mentality, he now came to believe that the war would serve progressive causes: that it would sweep away military despotism and advance the causes of nationality, liberty and democracy throughout Europe. A 'patched up' peace 'on the basis of the status quo' was, therefore, unthinkable: military empire had to be smashed, and Europe remade along national lines. It was this that justified even the alliance with tsarist Russia: 'the idea that because Russia has an internal system of government that we disapprove, the people of Russia cannot go on a crusade of liberty abroad will be dispelled in anyone who stands beneath the statue of the Tsar Liberator in Sofia.' Russia was engaged on behalf of 'the suppressed nationalities' of Eastern and south-eastern Europe, and this was 'their war of liberation'. ${ }^{36}$

He was convinced that the war was fundamentally a struggle for nationality: 'study the race map of Europe', he advised a friend in December 1914, 'if you want to see why there has been a European war'. But 'the Germans and their allies had to be beaten before they would recognise the nationalist principle

\footnotetext{
32 Trevelyan, 'A holiday among the Servians', p. 163; Trevelyan, G. M. to Robert Trevelyan, 20 July 1913, in Raina, George Macaulay Trevelyan, p. 80; Feske, From Belloc to Churchill, pp. 163-5.

33 Trevelyan, G. M. 1920, Lord Grey of the Reform Bill, Longmans, Green \& Co., London, pp. 67-72 (pages written in late July 1914); Trevelyan, G. M. to Lady Caroline Trevelyan, 24 July 1914, Trevelyan Papers, GOT 105; Moorman, George Macaulay Trevelyan, pp. 123-4.

34 'The peril to civilization: Mr G. M. Trevelyan and "The Balance of Power", Daily News \& Leader, 3 August 1914 (war was declared the next day).

35 Moorman, George Macaulay Trevelyan, pp. 127-8; Cannadine, G. M. Trevelyan, p. 78 ff. The phrase recurs in many of his letters to his family from mid August 1914.

36 Trevelyan, G. M. 1914, 'When the war is over', McClure's Magazine, [New York], vol. XLIV, no. 2, pp. 37-8; 'Slav and Magyar: the "Curse of Ham" theory', Daily News, 15 March 1915.
} 
in the form of home rule, redistribution of territory or otherwise' ${ }^{37}$ For the configuration of 1914 appeared to replicate that of 1815; and the alliance of Germany, Austria-Hungary and Turkey allowed prowar liberals like himself to equate nationalism with liberalism in south-eastern Europe and the Near East. As he explained in another 'take' on nineteenth-century history: after 1848'the liberal turning point where Europe failed to turn' - nationalism had also assumed a virulent form. The failure of liberal revolution corrupted liberalism: the German parliamentary movement 'turned rabid'; the Hungarian national ideal was deflected into 'the racial absolutism' of the Dual Monarchy. And, with the 'Blood and Iron', non-liberal unification of Germany, the success of Bismarck's policies merged 'military despotism' and nationality into 'an active principle': 'efficient, boastful, contemptuous in the name of modern science and culture of "the retrograde formulas" of liberty' - a spirit that corroded international relations, dominated Germany, Austria-Hungary and the Turkish Empire, and insinuated itself into Disraeli's Britain and Italy, where imperial delusions eroded the 'humane... liberal tradition' in both countries. ${ }^{38}$

But even before 1914, the Bismarck system gradually had unravelled. The despots fell out amongst themselves. Tsarism confronted Prussianism. 'The Concert of Europe', anaemic heir of the Holy Alliance, could not sustain the Turkish 'Chamber of Horrors'. Austro-Hungarian expansion met its match in the peasant democracy of Serbia. And the war unleashed by the Central Powers to hold back nationalism and perpetuate military empire turned instead into the belated finale' of the struggle against the ancien régime. The Great War, then, was not just a war of national liberation, but also a crusade for liberal democracy: a clash of political and social systems, which pitted regimented Prussians against the 'children of revolution' in France, and eventually in Russia and America also, and semi-feudal Austrian-Magyar landlords with their reluctant peasant conscripts against the free yeoman farmers of Serbia and Italy. ${ }^{39}$

As the celebrant of Italian liberation, Trevelyan was used to seeing the Hapsburg Empire as the prison-house of nations. Also, recent visits there had convinced him 'there could be no lasting peace in Europe until [its subject] races... obtain[ed] self-government'. As a member of the Balkan Committee, he was also conditioned to respond to the propaganda of Balkan independence. But unlike most of his colleagues, he viewed the Balkan and Austro-Hungarian problems as one and the same: 'for this reason - that...the South Slav and the Romanian

37 Trevelyan, G. M. to J. L. Hammond, November or December 1914, Hammond Additional. Mss. Eng.c. 5787, ff. 81-2, Bodleian Library, Oxford; Trevelyan, 'When the war is over', pp. 34, 39-40.

38 Trevelyan, 'From Waterloo to Marne', pp. 79, 83-5; Trevelyan G. M. 1919, The War and the European Revolution in Relation to History, pp. 35-6, 38.

39 Trevelyan, 'The four great wars', p. 271 ff; Trevelyan, G. M. to G. O. Trevelyan, 27 and 29 March 1917, 7 April 1917, Trevelyan Papers, GOT 109; Trevelyan, G. M. 1915, 'Serbia revisited', Contemporary Review, vol. cvii (March), pp. 273-83; Trevelyan, G. M. 1915, articles in Daily News, 4, 14, 19, 20 and 27 January and 1 March. 
race are each cut in half, one half free in the Balkans, the other subject to the Emperor Franz Joseph.' Austria-Hungary, he explained, was formed long before the age of nationalism under the imperatives of dynastic accumulation and Catholic reconquest, 'at the expense of the Turk...but no less at the expense of the future freedom of the races...then delivered' ${ }^{40}$ Twelve years before the war, he recalled in October 1914, he had gone to Hungary, an enthusiast for 'the gallant Hungarian country gentlemen', who had fought so nobly for their...liberty in 1848', and in 1867 had won racial parity within the Empire. They had, however, 'never conceived the idea of granting it to others', but 'treated the Romanians and Southern Slavs like barbarians'; in Transylvania, he was reminded of Ireland, with the Magyars as the garrison landlords of the Protestant ascendancy, 'dwelling amongst an alien... hostile people' ${ }^{41}$

In the Balkans things were worse. Gladstonians, like his father, had all deplored the role Britain had played at the Berlin Congress of 1878. What they excoriated, however, was the propping up of Turkish rule, while what he retrospectively attacked was the sanctioning of the Austrian occupation of Bosnia. This 'fragrant violation of the national principle', he said, enabled the Dual Monarchy to 'tie Serbia up in a sack' and to deny the young state 'natural expansion' to its 'racial littoral' on the Adriatic. Since in his view Serbia and Bosnia were 'in reality one country divided in half', the acquisition-after the 1908 formal annexation - of Bosnia tied the Austro-Hungarian elites to domestic repression and a belligerent, 'suicidal' foreign policy. Disconcerted by the rise of Balkan nationalism, threatened by adjacent independent nationstates and by 'unredeemed' nationals and 'nationalist movements' inside their empire, they saw Serbia especially as their 'deadly foe'. Twice the monarchy planned a pre-emptive war; twice her allies refused support. Eventually, the murder of the Archduke by Bosnian-Serb freedom fighters provided them 'a fitting opportunity to wipe Serbia off the map'. But he was hopeful that what had started as 'a punitive Austro-Hungarian expedition' would turn into a war of liberation for the Southern Slavs, with Serbia in the role of 'a hero-nation, similar to that undertaken by Piedmont for the other Italian provinces' ${ }^{42}$

But, as his friend the radical historian J. L. Hammond pointed out, the analogy was forced. 'Italy was wholly Italian; Bosnia and the other coveted Austrian provinces...Serb though they [we]re in race [we]re only one-third Serb in

40 Trevelyan, 'When the war is over', pp. 183-4; Trevelyan, G. M. 1914, 'The new map of Europe', English Review, vol. 18, pp. 488-9.

41 Trevelyan, G. M. 1914, 'The Magyar tragedy', Nation, 10 October, pp. 33-4.

42 Trevelyan, G. M. 1914, The Servians and Austria, The Victoria League, London, pp. 6-12; Trevelyan, G. M. 1914, 'The Servian people', The Times, 18 September; Trevelyan, G. M. 1915, 'Serbia and southeastern Europe', Atlantic Monthly, (April), pp. 126-7; Trevelyan, G. M. 1915, 'Austria-Hungary and Serbia', Fortnightly Review, (June), pp. 978-86. 
politics and creed. ${ }^{43}$ Like most of his British contemporaries, Trevelyan was convinced of the ethnic unity of the Southern Slav-or, in a typical slippage, 'the Serbian race', a term he applied promiscuously to the inhabitants of Serbia, Montenegro, Croatia, Slavonia, Dalmatia, Slovenia, Bosnia, Herzegovina, Kosovo and northern Macedonia. Their disparate political, religious and cultural histories - the divisions of Cyrillic and Latin, Orthodox and Roman, Muslim and Christian, independent successor states that had achieved nationhood at the price of an extra century and a half of Turkish rule and those that remained subject to the Emperor Francis Joseph-like the divides of pre-Risorgimento Italy, were fruit of a distorted history, which 'a resettlement of the European state system on the basis of nationality' would surely sweep away. ${ }^{44}$

Consequently, he never distinguished between a Greater Serbia, an enlarged Serbian nation-state, and a federal state of nations, a Yugoslavia, in which Serb and Croat, Bosnian and Slovene would enjoy some degree of autonomy. Bred on Mazzini's notion of a homogenous nationhood, founded in a common culture and shared political consciousness, and achieved through the exercise of popular will - as a tidy marriage of state and culture - he did not allow for the likely violence and brutality of any unification process, where political units were so brittle and ill defined, and the sense of historical victimhood was so strong, and where nation-states could only be created through forcible and contested political and cultural engineering. Nor did he grasp 'the narcissism of small differences': the fact that ethnic and linguistic proximity, coupled with divergent historical experiences, might simply allow the interested parties to exchange myths and confirm prejudices with greater facility. ${ }^{45}$

As one of the 'few Englishmen' who had visited Serbia before the war, he thought it his duty to show his countrymen 'what the Serbians are really like'. Serbia, he said, had all 'the virtues and the limitations of a peasant democracy'. Since nearly all the population consisted of yeoman farmers cultivating their own farms, it was remarkably democratic and egalitarian; there were no class questions to speak of, 'no social problem', and consequently 'no vital politics except foreign politics': 'patriotism' was 'the sole political feeling of the average Serbian'. It was this that explained 'the unanimous and spontaneous devotion of

43 Hammond, J. L. 1915, 'Serbia and the war', Nation, 3 July 1915; Hammond, J. L. 1915, 'A war for the ideals of $1789^{\prime}$, Nation, 17 July.

44 Trevelyan, 'When the war is over', pp. 38-9; Trevelyan, G. M. 1915, 'What are we fighting for?', War and Peace, (April), pp. 103-5.

45 Ignatieff, M. 1997, 'The narcissism of minor differences', The Warrior's Honor: Ethnic war and the modern conscience, Henry Holt \& Co., New York; Ignatieff, M. 1999, 'Nationalism and the narcissism of minor differences', in R. Beiner (ed.), Theorizing Nationalism, State University of New York Press, Albany, pp. 91102. The term was first coined by Sigmund Freud in 1917. 
the Serbian nation in arms': a natural fellowship of officers and men comparable with that of the early American and First French Republic_-'as co-partners in the national defence' ${ }^{46}$

Serbian nationalism was one of blood, soil and belonging; but he was persuaded that the Serbs, like the Italians, would soon learn liberal, constitutional ways. The war, he said, had stimulated a desire for 'personal, commercial, intellectual and educational...connections with England', and he was hopeful that 'the great outburst of British sympathy for Serbia in the last few months has laid the foundations for a close friendship...similar to that which has bound Italy to this country by the memory of the sympathy and aid we gave in the hour of their birth-throes' ${ }^{47}$

He was the embodiment of that friendship; and the war, it seemed, might bring about the sort of identification he had achieved with all things Italian. Along with other activities during the autumn, he worked for the Serbian Relief Fund, wrote and lectured on the Serbian cause under the auspices of various British propaganda organisations, and in December was sent with Seton-Watson on a diplomatic mission to Belgrade. Partly humanitarian and morale-raising, it was also designed as the first step of an ambitious strategy to secure the support of all the Balkan peoples. The prospective confederation was, of course, easier to conceive than to deliver, and it soon foundered on their lack of official accreditation and on the ethnic differences, mutual suspicions and competing territorial ambitions of the interested parties. ${ }^{48}$

Trevelyan's role in this, though peripheral, was symptomatic. For, by the time he left for Serbia early in December, his Italian sympathies had begun to cloud the purposes of his mission. In August 1914, his greatest anxiety had been that Italy might enter the war alongside the Central Powers as a member of the Triple Alliance. So he was greatly relieved when she had stayed neutral. In fact, there was never much chance that Italy would fight alongside her ancient enemy Austria, the possessor still of the 'unredeemed provinces' of Trieste and the Trentino. And once she had defaulted on her treaty obligations, there were grounds to suppose that she might go one step further and join the Allies. Somewhat artlessly, Prime Minister Salandra had defined his government's policy as a 'sacred egoism' for Italy; and for his Foreign Secretary, the egoism focused obsessively on the Adriatic. Convinced that the Trentino and Trieste were insufficient to convince neutralists of the merits of intervention, and that

\footnotetext{
46 Trevelyan, 'Serbia revisited', pp. 274-5.

47 Ibid., p. 274. British, of course, considered coterminous with English.

48 Moorman, George Macaulay Trevelyan, pp. 130-3; Seton-Watson, H. and Seton-Watson, C. 1981, The Making of a New Europe: R. W. Seton-Watson and the last days of Austria Hungary, Methuen \& Co., London, pp. 105-17; Seton-Watson, H. and Seton-Watson, C. 1976, R. W. Seton-Watson and the Yugoslavs. Volume 1, [Letters of Seton-Watson and Trevelyan in Serbia and Romania, January and February 1915], British Academy, London, pp. 21 ff, 193-7; Trevelyan, G. M. 1915, articles in Daily News, 4, 14, 19, 20, 27 and 29 January.
} 
Italy's vital interests as a Great Power could only be satisfied by control of the eastern Adriatic coastline, he was determined to secure as much as possible in Istria, Dalmatia, Bosnia and Albania, however much this might poison relations with her prospective co-belligerents and compromise the Allies' position in the Balkans.

This placed Trevelyan in a cleft stick. A notorious Italophile, he was also one of the first to urge the claims of Serbia as 'the nucleus of a new Jugoslav state', which was to include Croats, Slovenes and Bosnians. After his return from Belgrade in March 1915, he was involved in a number of propaganda exercises - lecture tours, manifestoes, public celebrations and the like in England and Americadesigned to show 'that the Serbs and Croats have a culture of their own... and regard themselves as a single people with two names' ${ }^{49}$ He had accused Austria of tying Serbia up 'in a sack'. Was not Italy about to do the same? Seton-Watson and the Yugoslav lobby certainly thought so. The promise of the Adriatic coastline to Italy under the terms of the Secret Treaty of London was, they said, 'a flagrant betrayal of the cause of nationality' and 'a crime against the Serbo-Croat nation', which could only be enforced by 'brutal force', would demoralise the Serbians and destroy Allied credibility in the Balkans. Of course, the public was treated to much misinformation. But that, too, was a problem: the competing claims of co-belligerents could only be met by secret treatieshallmark of the old, discredited diplomacy - designed to disguise the extent of one ally's 'sacred egoism' at the expense of another. ${ }^{50}$

In May 1915 Trevelyan was sent to Rome to promote closer understanding between Britain and Italy and to stiffen wavering Italian resolve. And he had witnessed the famous street demonstrations, led by Nationalists like d'Annunzio and Mussolini, which had toppled neutralist doubters in Parliament and stampeded the Government into declaring war. Predictably, he invoked the names of Garibaldi and Mazzini, and hailed the so-called 'radiant days of May' as the last act of Risorgimento drama, which was to reclaim Italy's 'unredeemed provinces' from Austria-Hungary. Mazzini and Garibaldi, he said, had triumphed over Machiavelli; Italy had rediscovered her soul and reaffirmed 'her political liberty and her instincts for humanity and justice'.$^{51}$ From the vantage point of subsequent history, however, the combination of extra-parliamentary forces-

49 Moorman, George Macaulay Trevelyan, pp. 134-6; Trevelyan, Daily News, 1 and 15 March 1915; The New York Times, 25 April and 22 May 1915. (In London, for example, he was an organiser of the exhibition of Serbo-Croatian art in the Victoria and Albert Museum, featuring the Croat sculptor Ivan Mestrovic, June 1915; see The Times, 25, 26 and 28 June 1915; Anon. 1919, Ivan Metrovic, A Monograph, Victoria and Albert Museum, London.)

50 Seton-Watson and Seton-Watson, The Making of a New Europe, pp. 121-7; Seton-Watson and SetonWatson, R. W. Seton-Watson and the Yugoslavs, pp. 224-7; Seton-Watson, R. W. 1915, 'Italy and Dalmatia', Nation, 29 May.

51 Trevelyan, G. M. 1915, 'What Garibaldi saw: Mazzini and the present war', Daily News, 8 March; Cannadine, G. M. Trevelyan, pp. 80-1; Trevelyan, G. M. to F. Jackson, 21 May 1915, 1915, Jackson Papers 
irredentists, annexationists, 'Nationalist men of order', futurists, revolutionary socialists - all baying for war against an unheroic liberal political establishment, could also be depicted as a dress rehearsal for the fascist coup d'état of 1922 . On the matter of the Adriatic, also predictably, he temporised. But he found his balancing act at the hub of Italian politics, trying to square his Italian and Serbian alter egos, deeply uncongenial. So much so, that in another personal U-turn, he availed himself of the opportunity for front-line action instead, as Commandant of the 1st British Red Cross Ambulance Unit in northern Italy, thereby combining his yearning for service with his revulsion against the Realpolitik inseparable from the diplomatic war effort.

For the duration of the war, he was able to ignore the difficulties of his commitment both to 'race nationalism' and to liberal democracy. Indeed, the events of 1917 confirmed his conflation of the two: the February revolution in Russia that toppled tsarism and the tsarist empire - always an embarrassmentwas, he said, 'the first great triumph of the principles for which we are fighting': proof that the war could promote liberal outcomes. ${ }^{52}$ And 'the entry of American democracy' on the Allied side two months later, which 'turned the tables on the whole ancient order of ideas in Europe', transforming the conflict, as had the Protestant hero Gustavus Adolphus in another European civil war some 300 years before, promised 'to liberate the world once and for ever from suicidal mania, by the destruction of military despotism in its ancient lair'. For Trevelyan, as for many other liberals, US President Woodrow Wilson's Fourteen Points were a sure guarantee of a new peaceable international order: a league of nations, self-determining, independent, liberal and democratic. ${ }^{53}$

With the end of the war in 1918, however, he could no longer evade the problems shelved in 1915. He spent fruitless weeks around the Versailles peace talks, trying to mediate between the Italians and the new Yugoslav authorities. But since 1915, he had stopped thinking about Serbia: 'I keep whole chambers of my brain sealed up for my health', he told his mother-in-law, 'and one is labelled "Serbia"'. His hopes that the Serbs would become good liberals had withered once Serbia was overrun in a second national 'Golgotha' in 1915-16; all they would want, he feared, was ethnic 'revenge'. ${ }^{54}$ His experiences on the Italian front, moreover, had deepened his attachment to Italy, and he was something of a dishonest broker: rejoicing, as he entered Trieste in November 1918, at the city being 'united to her mother Italy after many years of longing';

[loose], Trinity College, Cambridge; Trevelyan, G. M. 1919, Scenes from Italy's War, Longmans, Green \& Co., London, pp. 1-22; Trevelyan, G. M. 1915, 'Italy at war', Nation, 10 July; Trevelyan, G. M. 1915, 'Rome in wartime', Daily News, 14 July.

52 Trevelyan, G. M. to G. O. Trevelyan and Caroline Trevelyan, 20 March and 8 July 1917; Trevelyan, G. M. to Charles P. Trevelyan, 24 March 1917, Trevelyan Papers, GOT 109, CPT 241.

53 Trevelyan, 'The four great wars', pp. 266-7.

54 Trevelyan, G. M. to Mrs H. Ward, 20 March and 19 October 1916, Trevelyan Papers, MM 1/2/2; Moorman, George Macaulay Trevelyan, p. 153. 
'smoothing' Italian egos with exaggerated accounts of their heroic war efforts; and defending their Mediterranean appetites as 'a hankering for small sugar plums' compared with the vast colonial acquisitions of Britain and France. ${ }^{55}$ Identity is invariably relational, and Trevelyan could only define his postwar Italian persona by shuffling off the Serbian sympathies of yesteryear. When President Wilson accused Italy trying to strangle the infant Yugoslavia at birth, Trevelyan angrily demurred, telling his mother he 'hate[d] Wilson now', and referring to Italian citizens 'beyond the frontier' who needed protection 'from oppression by an alien and traditionally hostile race', and seeking to counter what he described as 'the shrill, one-sided attacks' of the Yugoslav lobbyspecial pleading, which his brother dismissed as 'the most beastly jingoism on behalf of his beloved Italians'.$^{56}$ In December 1920, in the teeth of the widespread nationalist excesses in the Mediterranean and Adriatic, he still sought to preserve a clear distinction between the brutality and ethnic exclusivism of its south-eastern and Eastern European manifestations and what he professed to be the liberal, universal legacy of the Risorgimento, so 'thoroughly in keeping with the fundamental kindliness and good sense of the Italian nature' - this more than a year after d'Annunzio's march on Fiume, at a time when fascism was taking root in northern and central Italy. ${ }^{57}$

But he found the rise of Mussolini and the abrupt termination of liberal parliamentary democracy difficult to square with his interpretation of Italian nation-making. For if the Italians were as freedom loving as he insisted and if the Italian state had been a model marriage of nationalism and liberalism, how could Mussolini's authoritarian regime have come about? The new regime's apologists were to argue that fascism not parliamentary liberalism embodied the spirit of 1915 and 1860. And certainly there were strong continuities of policy and personnel, not least in the person of the King. But to Trevelyan, fascism could not be the heir of the Risorgimento. Rather, the gradual eclipse of the Risorgimento tradition and the failure of its official inheritors were to blame. Before the war and again after 1919, the parliamentary elites had corrupted political mores. Political parties turned into venal factions; graft became rampant;

55 Moorman, George Macaulay Trevelyan, pp. 153, 188; Trevelyan, Scenes from Italy's War, Preface, pp. 10-12, $188 \mathrm{ff}, 233-4$. 'Many years of longing' indeed, as Trieste had been a Hapsburg possession since 1386! 56 Trevelyan, G. M. 1919, Englishmen and Italians: Some aspects of their relations, past and present, British Academy, London, pp. 108-9; Trevelyan, G. M. 1918, 'A plea for moderation', Manchester Guardian, 30 December; Trevelyan, G. M. 1919, 'In the cause of right, GMT on Italy's sacrifice', The Times, 22 February; Trevelyan, G. M. 1919, 'Italy's peace', The Times, 12 December; Moorman, George Macaulay Trevelyan, pp. 187-8; Trevelyan, G. M. to Lady Caroline Trevelyan, 29 November 1919, Trevelyan Papers, GOT 111; Morris, T. A. 1997, 'Trevelyan, G. M., to Charles P. Trevelyan, 15 December 1919', C. P. Trevelyan, Portrait of a Radical, Blackstaff Press, Belfast, p. 143.

57 'Letter to editor', History, vol. IV (January 1920); Trevelyan, G. M. 1920, 'New preface', Garibaldi and the Thousand, December 1920, p. iii; Trevelyan, G. M. 1920, 'Napoleon and Italy', The Times, [Special Supplement], 20 December. 
bureaucracy was compromised; and parliamentary government, in 1915 tainted by its 'political and cultural vassalage' to Germany, was now damaged by its inability to preserve order. ${ }^{58}$

It was the stock apologia for authoritarian reaction all over Europe. In the 'semiBolshevist' revolt, which infected every war-ravaged society, Italian socialists 'had adopted the methods of violence in place of the ballot'. The restoration of order and security could only come about through 'fearless exercise of power and authority' by a government 'strong enough' to tackle 'parliamentary graft' and to harness the spirit of 1860: 'a popular propaganda of patriotism.' Despite - he was not ready to say because of - the legacy of Mazzini and Garibaldi, parliamentary government had never gained a firm foothold in Italy. For, as he admitted, parliamentary institutions were something of an innovation in Italian history as a whole. 'The Italians', he had written, 'are not a great parliamentary nation but they are a great democratic nation'. Political issues invariably were settled by demonstrations, marches and 'rows in the piazza': 'the Populo goes down into the streets and takes things into its own hands.' Even Garibaldi believed in 'good violence': that 'an honest dictatorship [was] the best means of carrying out the democratic will in times of crisis.' ${ }^{59}$

Mussolini's revolution - part coup, part street theatre, part manipulation of elites - was, then, part of an older, populist Italian tradition. Order always preceded liberty; even in England, freedom of speech and person were relatively recent. Perhaps, he suggested, in the long run the fascist state would prove analogous to Tudor despotism after the anarchic Wars of the Roses: a temporary swerve from the path of liberty in the direction of executive authority. But the parallel was forced; and, by 1928, it was clear even to him that Mussolini was not a mixture of Henry VIII and Garibaldi, but a dictator who had 'suppressed every vestige of liberty with an efficiency far surpassing that of the Bourbons and Austrians of old'. As for fascists, they were the new Jacobins who sought 'to abolish the easy kindly temperament of the Italian people and 'drill and bully' them into becoming 'second rate Germans' ${ }^{60}$

After 1923, he stopped writing Italian history. But he would not condemn Italy publicly. Even in 1935, though privately he deplored the Italian invasion of Ethiopia, he refused to lend his support to the call for sanctions and resigned from the League of Nations Union in protest. It had always been inevitable, he said, that a united Italy would eventually become a great Mediterranean and African power; and what had been thwarted at Adowa and at Versailles, where

58 Trevelyan, G. M. 1923, The Historical Causes of the Present State of Affairs in Italy, University of London, Athlone Press, London, pp. 15-20.

59 Ibid., pp. 8-9; Trevelyan, Garibaldi's Defence of the Roman Republic, p. 163; Feske, From Belloc to Churchill, pp. 165, 167.

60 Cannadine, G. M. Trevelyan, pp. 82-3, 85. 
she was denied the colonial mandates promised her in 1915, had now occurred. Two years later, convinced that Anglo-Italian friendship was 'essential to peace', he applauded Chamberlain's 'cheerful courage' in initiating talks with Il Duce, and fully backed the policy of mending diplomatic fences through appeasement. $^{61}$

As a liberal internationalist, he was committed to the principles of national selfdetermination, minority rights and open covenants embodied in the League of Nations. But thanks to American withdrawal and to British and French manipulation, he believed that instead of acting as 'a clearing house for peaceful change...to keep pace with national tendencies', the league had become an instrument of perpetuating a distorted status quo. He considered the creation of an irredentist Germany the worst of all the evil legacies of the war. And he refused to allow his loathing of the Nazi regime to affect his judgment on what he saw as legitimate frontier revision from the early 1920s through until 1939, in Silesia, East Prussia, the Saarland, Austria and the Sudetenland. This seemed to him to embody the right of the majority to decide their political future in a manner not dissimilar to what, as a liberal, he once had claimed for Boers, Italians, Serbs and Bosnians. Indeed, the analogy he chose as late as 1938 for the Anschluss with Austria, was the benign one of 1860, and the 'scandalous breaches of peace and international law' perpetrated by Garibaldi and Cavour in 'the forcible union of the Papal States and Neapolitan Kingdom with Piedmont'. Even over Czechoslovakia, he agreed with Ernest Barker, arguing that the issue was between mutually exclusive liberal ideals: support for a liberal-democratic multinational state and for the principle of self-determination:

In the nineteenth century English liberals and democrats could sympathize with national movements in Europe because they were or seemed to be, liberal and democratic as well as national. Those days are gone... One might regret that the Bohemian Germans should prefer to follow the call of national feeling at the cost of surrendering membership of a democratic state, but that is their preference. ${ }^{62}$

By 1939, however, the attempt to combine liberalism with enthusiasm for every expression of national self-determination however illiberal-including ethnic Gleichschaltung, dictatorship and aggressive imperialism-had become too

61 Trevelyan, Janet, George Trevelyan and H. Goad, Director of the British Institute, 1936, Goad Papers [16 January 1936], British Institute of Florence; Trevelyan, G. M. 1939, 'The Anglo-Italian agreement: a cloud lifted', The Times, 19 April; 'Keeping the peace', The Times, 25 April 1938.

62 Trevelyan, G. M. 1937, 'Epilogue', History of England, [new edn], Longmans, Green \& Co., London; Trevelyan, G. M. 1937, Grey of Fallodon, Longmans, Green \& Co., London pp. 356-9; Barker, E. 1938, 'Letter to the editor', The Times, 26 September; GMT-Rowse, A. L, 28 September 1938, Rowse Papers [unsorted], Exeter University; Trevelyan, G. M. to M. Moorman, 16 March and 30 September 1938, Trevelyan Papers, MM 1/4/26. 
hard. And, on 10 June 1940, when Italy declared war on Britain and Francethe 'bitterest day of [his] life', he said-he reached the end of the international line. ${ }^{63}$

Since the mid 1920s, he had retreated from Europe and had returned to the university; the 'causes' he attached himself to were now almost entirely domestic and apolitical - the National Trust, the Youth Hostels Association (YHA), Outward Bound, the Pilgrim Trust-and his writing focused on the celebration of English exceptionalism, notably in his History of England of 1926 and England under Queen Anne of 1930-34. The first was full of 'the peculiarities of the English': the 'Mingling of the Races...from the Earliest Times', 'the Making of the Nation' and of 'a distinct English nationality' in the Middle Ages, the creation of a national church and the growth of 'seapower' under the Tudors - when 'the English grown to manhood dismissed their Latin tutors' and 'Britain bec[a]me a world by itself' - the development of parliamentary institutions and of religious pluralism in the seventeenth century and the gradual but uninterrupted movement towards democratic control ever since. But the traditional Whig story was broadened to include Seeley's idea of England as a living organism, a nation in the process of 'continuous expansion into Greater Britain' ${ }^{64}$

England and Britain - the domesticated and imperial idioms of national identity - conducted their familiar 'pas de deux' over the past three and a half centuries, wherein British history was continuous and usually coterminous with the story of England. Perhaps it came naturally to a Northumbrian. All the same, Trevelyan knew that the British imperial state forged in the eighteenth century was a peculiar invention: the outcome of dynastic chance, religious choice, and political and economic calculation. But his treatment of its making was bland and congratulatory. Neither in his general history nor in his Queen Anne Trilogy was there any acknowledgment of the costs to the geographically or socially marginal of the Union, the Hanoverian Succession, the Whig oligarchy and the absolute rule of property. ${ }^{65}$ In 'the age of the League of Nations', where 'conferences, compromises [and] concessions' were essential to mutual survival, the Anglo-Scottish parliamentary union of 1707 was for him a timely lesson in imperial wisdom and initiative. The two peoples were reconciled 'on terms of equality and justice': Scotland, released from 'poverty and isolation', was

63 Trevelyan, G. M. 1940, The Spectator, 10 June; Trevelyan, G. M. to M. Moorman, 14 June 1940, 'Easter Sunday' 1940, Trevelyan Papers, MM. 1/4/27-28.

64 Trevelyan, G. M. 1926, History of England, Longmans, Green \& Co., London, chapter headings, pp. xxi-xxii, 480-2.

65 Trevelyan, History of England. Even for the 1920s, his comment on the Highland Clearances is rather shocking: 'an Afghanistan could no longer be tolerated within fifty miles of the "modern Athens"' (p. 538). 
able for the first time to fulfil her economic, intellectual and artistic potential; and 'the British Empire became much greater and in every sense richer than an English Empire could ever have been' ${ }^{66}$

Yet in 1940 it was to a still implicitly English empire he appealed. 'All Englishmen [we]re in the Front-line now': 'internationalism', he said, 'is not enough, and it is a good law of nature that we should rejoice in our own land' ${ }^{67}$ Recalling the struggles against Spain and France from the sixteenth to the nineteenth centuries, he retreated into patriotic contemplation of his own English/British national identity, which was again under threat, but was politically and culturally securely grounded in history: nostalgically celebrating the literature and landscapes of 'Englishry' in Chaucer's, Shakespeare's, Dr Johnson's and Cobbett's times - a social history which, he said, 'might be defined negatively as the history of a people with the politics left out', but which possessed 'its own positive value and peculiar concern'. And in a return of the repressed or what might be called 'Wallington Revisited', he outlined its scope: 'the character of the family and household life, the conditions of labour and of leisure, the attitude of man to nature [and] the culture of each age as it arose out of these general conditions of life. ${ }^{68}$

What then does this briefly sketched personal trajectory over 40 years - with its continuities and unchanging assumptions, but also its changing contexts, agendas and enthusiasms - have to offer the student of nationalism? Perhaps, one can argue, it offers just this: a way of looking at nationalist thinking, grounded in a real-life story and shifting real-life situations. As such, it may allow one to trace connections, relationships and modulations sometimes obscured in generalist, sociologically driven inquiries. In many respects, Trevelyan was a representative liberal of his era, but his interests and experiences and especially his ways of interpreting them historically were quite distinctive and were by no means fully shared by his contemporaries. His biography can therefore serve as 'a prism of history', by articulating the ways in which a 'mind meets the world', exploring the tensions or what E. P. Thompson called 'the nodal points of conflict' between the individual and the social/political worlds he

66 Trevelyan, G. M. 1932, England under Queen Anne: Ramillies and the Union with Scotland, Longmans, Green \& Co., London, pp. 174-5, 285-6; Trevelyan, G. M. 1929, 'The parliamentary union of Scotland and England', The Listener, vol. XX, pp. 669-71, 697-8; Trevelyan, History of England, pp. 538-9; Cannadine, G. M. Trevelyan, pp. 115-16.

67 Trevelyan, G. M. 1940, 'All in the front-line now: are we ready in heart and soul?', Sunday Times, 7 July; 'For ever England', The Observer, 3 December 1944. The latter was a review of Francis Brett Young's epic war poem 'The Island' from 1944, a celebration of national identity even more riveted than Trevelyan's in traditional English rural values. Cannadine, D. 2002, 'Emollience, Stanley Baldwin and Francis Brett Young', In Churchill's Shadow, Allen Lane \& Penguin Press, London.

68 Trevelyan, G. M. 1944, English Social History, Preface, p. vii. This is a passage invariably misquoted and misunderstood. The allusion is, of course, to another English nostalgic exercise of the time: see Waugh, E. 1945, Brideshead Revisited: The sacred and profane memories of Captain Charles Ryder, Penguin Books, London. 
or she encounters. ${ }^{69}$ Precisely because the 'proper function of the biographer is to deal with the individual, the contingent and the instantaneous', because biography is a descriptive mode of narration, happily resistant to theory-'a form of understanding that consists in seeing connections' - it may even act as a corrective to studies of nationalism, which suffer from a surfeit of theorising or ahistorical model-building, and 'a craving for generality', as Wittgenstein puts it, 'born out of $[a]$ preoccupation with the method $[s]$ of science'.$^{70}$

69 Tuchman, T. 1979, 'Biography as a prism of history', in M. Pachter (ed.), Telling Lives, The Biographer's Art, New Republic Books, Washington, DC; Kessler-Harris, A. 2009, 'Why biography?', American Historical Review, (June), pp. 625-30; Thompson, E. P. 1993, Witness against the Beast: William Blake and the moral law, Cambridge University Press, Cambridge, p. xix.

70 Monk, R. 2007, 'Life without theory: biography as an exemplar of philosophical understanding', Poetics Today, vol. 28, no. 3, pp. 527-70, especially pp. 529, 531-2, 546, $563 \mathrm{ff}$. 